\title{
Design of Fuel Anti-theft Based on Micro-controllers using Short Message Service
}

\author{
Andi Syofian ${ }^{1 *}$, Yultrisna ${ }^{2}$, \\ ${ }^{1}$ Institut Teknologi Padang, Department of Electrical Engineering, 25143 Nanggalo, Padang, Indonesia \\ ${ }^{2}$ Politeknik Negeri Padang, Department of Electrical Engineering, 25163 Limau Manih, Padang, Indonesia
}

\begin{abstract}
Theft of premium oil in Tank Trucks is very frequent done by irresponsible people. In general, the tank security system uses only the seal on the door of the faucet, therefore the seal can still be duplicated. To overcome this problem, its security system needs to be transferred to an electronic system with premium automatic delivery system control using HC-SR04 ultrasonic sensors and push-button. The system will send the fuel level information (premium) with SMS and display on the LCD when the charging or distribution is complete. There are 3 (three) premium levels that will be applied to the system. The first delivery condition of the tank is a 5 liter tank, the second condition from the tank to the gas station 13 liters and the third condition from the tank to the gas station 2 that is 2 liters. This system starts by activating the push button that functions as a motor drive switch and ultrasonic HC-SR04 sensor to detect premium level heights when premium sensitivity reaches heights will turn off the wiper motor driver. Premium volume will be informed to the user (the owner of the tank in the form of SMS using the SIM 900. The advantage of this tool is to detect premium theft in the premium tank by sending SMS ownership from the tank. This system can detect the theft of premium tanks via SMS, apply ultrasonic sensors (HC -SR04) to detect premium level heights the type of mass of the $0.76 \mathrm{~kg}$ premix affects the height at the volume of the tank. When the high volume of the 5 liter tank between the sensor and the premium is $7.63 \mathrm{~cm}$, when the 2 liter volume high between the sensor and the premium is $13,63 \mathrm{~cm}$, while at the time of empty tank ( 0 liters) the height of sensor with premium is $17,63 \mathrm{~cm}$.
\end{abstract}

\section{Introduction}

Premium is a clear yellowish color distillate oil. Premium in Indonesia marketed by Pertamina with a relatively cheap price because it obtains a subsidy from APBN Premium is the premium for the most popular motor vehicles in Indonesia. Premium in Indonesia marketed by Pertamina has a relatively cheap price because it obtains a subsidy from the state budget. But recently the rampant premium scarcity is a problem that has an impact on society, especially for people who drive. The absence of the premium will cause the vehicle to not operate. This prompted many cases of premium theft in Indonesia. This theft mode is done by the driver or other party when the distribution on the truck tank often occurs theft with the term "urine arbitrary" or reduce the premium charge before getting to the gas station by irresponsible elements. Truck tank is a truck designed to transport a liquid or gas load. Until now for the security of premium shipping through Pertamina tank

\footnotetext{
*Corresponding author: andisyofian@itp.ac.id
}

still handle it manually. So with the limited number of employees, all trucks can not be monitored optimally. On the system there is a push button to activate the wiper motor driver. The driver functions to control or disconnect and connect the current to the output to be used i.e. Motor Wiper. Wiper motor that will push it out and will stop when it is finished filling either to the truck tank or gas station 1 and gas station 2 with controlled by ultrasonic sensor that is HC-SR04. When the charging has finished LCD display will appear and sending SMS to the user about the remaining premium on the tank will be done in tandem [1-5].

\section{Literature Review}

Ultrasonic sensors are sensors that transmit sound waves and then monitor their reflections so that they can be used to determine the distance between sensors and objects that reflect back sound waves can be seen in Figure 1 below. One of the sensors that people often use in experimenting is HC-SR04. Handling distances range 
from $2 \mathrm{~cm}$ to $400 \mathrm{~cm}$, with a precision level of $0.3 \mathrm{~cm}$. Detection angles that can be handled no more $15^{\circ}$. The required current is not more than $2 \mathrm{~mA}$ and the required voltage is $+5 \mathrm{~V}$. The number of pins is 4 , the details of each pin can be seen in Table 1 below.

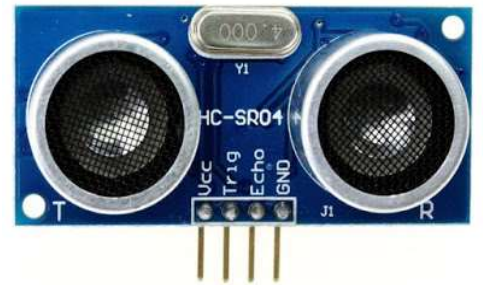

Fig. 1. Sensor Ultrasonik HC-SR04

Table 1. Pin configuration on sensor HC-SR04

\begin{tabular}{|c|l|}
\hline \multicolumn{2}{|c|}{ Distance $=$ Speed $* \mathrm{~T} / 2$} \\
\hline Pin & \multicolumn{1}{|c|}{ Information } \\
Pin1 & $\begin{array}{l}\text { Vcc (dihubungkan ke } \\
\text { tegangan }+5 \mathrm{~V}\end{array}$ \\
\hline Pin2 & $\begin{array}{l}\text { Trig (to transmit sound } \\
\text { waves) }\end{array}$ \\
\hline Pin3 & $\begin{array}{l}\text { Echo (to receive the reflection } \\
\text { of sound waves) }\end{array}$ \\
\hline Pin4 & Gnd (connected to ground) \\
\hline
\end{tabular}

SR04 The distance between the sensor and the object that reflects the sound waves is calculated using the following formula: Distance $=$ Speed $* \mathrm{~T} / 2$.

Arduino Uno is a microcontroller board based on ATmega328. Arduino Uno has 14 digital input / output pins (of which 6 can be used as PWM output), 6 analog inputs, $16 \mathrm{MHz}$ ceramic resonator, USB connection, power jack, ICSP header and reset button can be seen in Figure 2 below. built on what is needed to support the microcontroller, resources can use USB power (if connected to computer with USB cable) and also with adapter or battery. following Arduino Uno Atmega 328 can be seen in Fig.2.

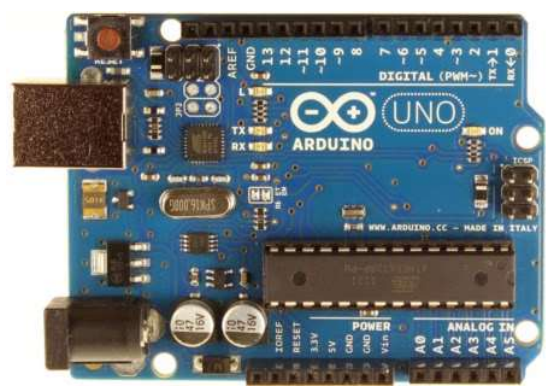

Fig.2. Board arduino uno 328
GSM Shield or GPRS (General Packet Radio Service) Shield is a product for your wireless Arduino needs. SIM 900 GPRS Shield can be seen in fig.3. Operates on GSM / GPRS 850/900/1800 / 1900MHz frequencies for voice, SMS and data transfers with low data consumption.

Shield GPRS is controlled using AT commands (GSM 07.07, 07.05 and SIMCOM Enchanced AT Commands). Compatible with Arduino UNO, Duemilanove, Seeeduino, Mega, and other compatible Arduino board. [3].

IComSat v1.1 SIM 900 GSM / GPRS shield has the following features:

a. It has four levels of network frequency (Quadband), which is $850 / 900 / 1800 / 1900 \mathrm{MHz}$.

b. GPRS data packet class 10/8.

c. Controlled with AT commands (GSM 07.07, 07.05 and SIMCOM enhanced AT Commands).

d. Power ON / OFF and reset function are supported by Arduino.them.

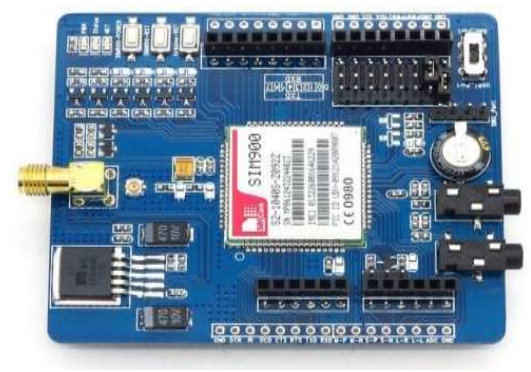

Fig.3. SIM 900 GSM shield

The data bus consists of 4 or 8 lines (depending on the mode of operation selected by the user). In 8 bit data mode, the path used is DB0-DB7, while for 4 bit data mode, the path used is DB4-DB7. Wiper motors are DC electric motors combined with natural magnets (ferrite magnets). As a stator and armature as its rotor. The following parts of the wiper motor can be seen in Fig.4.

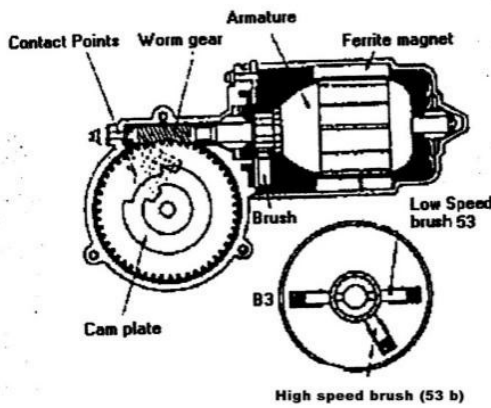

Fig.4. Parts of wiper motor

How it works Wiper motion is driven by a current flowed by the battery to the fuse and to the switch and onto the wiper motor so that the wiper motor can move properly. In Wiper, there are three movements that we 
often see that is slow (Low Speed), fast (High Speed) and slowly timed (Intermittent). Here is the movement of wiper motor seen in fig.5.

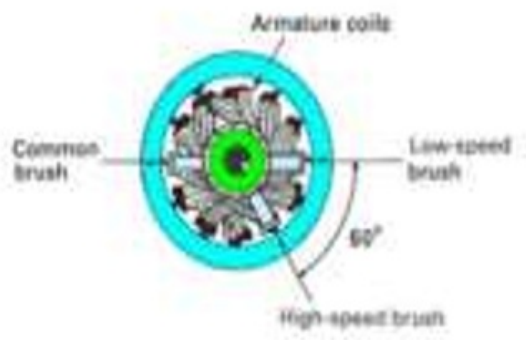

Fig.5. Movement of Wiper Motor

A relay is a device that operates on the basis of electromagnetics to drive a number of compacted contactors or an electronic switch which can be controlled from other electronic circuits by utilizing electric power as its energy source. The contactor will be closed (on) or open (die) due to the induced magnetic induction effect of the coil (inductor) when electrified.

Relay consists of 3 main parts, namely:

1. Common, is a part that is connected with Normally Close (under normal circumstances).

2. Coils (coils), are the main components of relays used to create magnetic fields.

3. Contact, which consists of Normally Close and Normally Open.

\section{Experiment and Analysis}

This test is done to find out the readability of sensors HC-SR04 and GSM shield, as shown in fig 6.

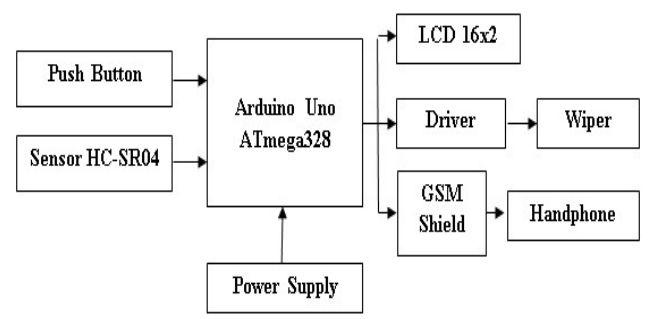

Fig.6. Block Diagram Prototype Premium Theft Detection on Microcontroller Based Truck Tank Using SMS Media (Short Message Service)

Tests performed at the measurement point (TP) can be seen in fig.7. Where measurements are made on the trigger pin and echo (sensor data) of the ultrasonic sensor.

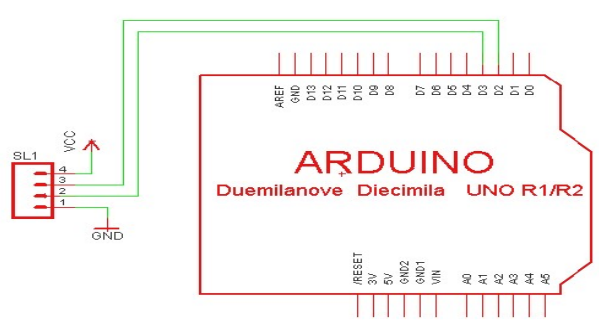

Fig.7. Trigger Voltage Measurement Circuit (TP1) and echo (TP2)

Table 2. Result of testing sensor distance

\begin{tabular}{|c|c|c|c|}
\hline No & $\begin{array}{c}\text { Actual distance } \\
(\mathrm{cm})\end{array}$ & $\begin{array}{c}\text { distance } \\
\text { sensor }(\mathrm{cm})\end{array}$ & $\begin{array}{c}\text { Eror } \\
\%\end{array}$ \\
\hline 1 & $10 \mathrm{~cm}$ & 10.06 & $0.6 \%$ \\
\hline 2 & $20 \mathrm{~cm}$ & 21.00 & $5 \%$ \\
\hline 3 & $30 \mathrm{~cm}$ & 32.37 & $7.9 \%$ \\
\hline 4 & $40 \mathrm{~cm}$ & 43.65 & $9.02 \%$ \\
\hline 5 & $50 \mathrm{~cm}$ & 54.51 & $9.20 \%$ \\
\hline 6 & $60 \mathrm{~cm}$ & 65.56 & $10.90 \%$ \\
\hline 7 & $70 \mathrm{~cm}$ & 77.68 & $13.70 \%$ \\
\hline 8 & $80 \mathrm{~cm}$ & 90.96 & $13.20 \%$ \\
\hline 9 & $90 \mathrm{~cm}$ & 101.88 & $14.10 \%$ \\
\hline 10 & $100 \mathrm{~cm}$ & 114.19 & $13.70 \%$ \\
\hline
\end{tabular}

From the results of Ultrasonic HC-SR04 sensor testing at the distance of the readable sensor with the distance measured manually (actual distance) there is a value difference $(+)$ indicates that the tool made the measurement result is greater than the actual tool. In addition, measurement errors can also occur due to rounding of calculations at the time of making the program.

Using calculations below:

$$
\begin{gathered}
\rho=\mathrm{m} / \mathrm{v} \\
\mathrm{V}=1 \text { liter }=1 \llbracket \mathrm{dm} \rrbracket^{\wedge} 3=1 / 1000 \mathrm{~m}^{\wedge} 3
\end{gathered}
$$

Information:

$\rho=$ density $\left(\right.$ premium $\left.=760 \mathrm{~kg} / \mathrm{m}^{\wedge} 3\right)$

$\mathrm{m}=\operatorname{mass}(\mathrm{kg})$

$\mathrm{v}=$ volume $\left(\mathrm{m}^{\wedge} 3\right)$

Here's a measurement table between the premium distance with the sensor: 
Table 7. Ultrasonic sensor readings of HC-SR04 with Premium.

\begin{tabular}{|c|c|}
\hline Volume & $\begin{array}{c}\text { Sensor distance with premium } \\
\text { oil }\end{array}$ \\
\hline 0 Liter & $17.63 \mathrm{Cm}$ \\
\hline 1 Liter & $14.63 \mathrm{Cm}$ \\
\hline 2 Liter & $13.63 \mathrm{Cm}$ \\
\hline 3 Liter & $11.63 \mathrm{Cm}$ \\
\hline 4 Liter & $9.63 \mathrm{Cm}$ \\
\hline 5 Liter & $7.63 \mathrm{~m}$ \\
\hline
\end{tabular}

The overall test of the tool aims to know that the whole system functions as being cool both input and output. As for reference work tool.

\begin{tabular}{|c|c|c|c|}
\hline $\begin{array}{c}\text { Sensor } \\
\text { Reader }\end{array}$ & SMS status & $\begin{array}{c}\text { Condition of } \\
\text { motor driver }\end{array}$ & $\begin{array}{c}\text { LCD } \\
\text { show }\end{array}$ \\
\hline 7.63 & Accepted & Off & $\begin{array}{c}\text { Shown } \\
\text { Time } \\
\text { Volume } \\
5 \text { Liter }\end{array}$ \\
\hline 13.63 & Accepted & Off & $\begin{array}{c}\text { Shown } \\
\text { Time } \\
\end{array}$ \\
& & & $\begin{array}{c}\text { Volume } \\
2 \text { Liter }\end{array}$ \\
\hline 17.63 & Accepted & Off & $\begin{array}{c}\text { Shown } \\
\text { Time } \\
\end{array}$ \\
& & & $\begin{array}{c}\text { Volume } \\
\text { Liter }\end{array}$ \\
\hline
\end{tabular}

\section{Conclusion}

Based on the above table it can be known, when the SMS will be received and at what distance the SMS will be received. The overall system test aims to know the course of the system, and to know the error that will occur on the system running so that the error can be anticipated and improved. In the table is known that the measured distance of the sensor will continue to increase along with the reduced premium detected.

\section{References}

1. Adi, Agung Nugroho mechatronics. Yogyakarta: PT. Graha Ilmu. (2010).
2. Kadir, Abdul, Practical Guide to Learn the Application of Microcontroller and Its Programming Using Arduino. Yoyakarta: CV. Andi Offset. (2012).

3. Kadir, Abdul. Arduino "Guide to Learn about Miscellaneous Microcontroller Based Projects". Yogyakarta: CV. Andi Offset. (2014)

4. Kadir, Abdul Smart Book of Arduino Programming. Yogyakarta: CV. Andi Offset. (2015).

5. Wekiardi, Hazni. Tugas Akhir. Short Message Service (SMS) Delivery Performation Analysis for prepaid subscribers on GSM network PT. Indosat Department Electrical engineering. Jakarta: Universitas Indonesia. (2008). 